TURIZAM

Volume 24, Issue 1

$1-12(2020)$

ORIGINAL

SCIENTIFIC PAPER

\title{
Reflections of Destination Quality on Destination Image: A Case of Kuşadasi
}

\author{
Janet Oluwakemi Abiodun ${ }^{A}$, Gökçe Özdemir ${ }^{B}$ \\ Received: November 2019 | Accepted: March 2020 \\ DOI: $10.5937 /$ turizam24-23848
}

\begin{abstract}
The image of a tourism destination is assembled on various resources including past encounters and marketing communications. However, the utmost important factor in increasing tourist arrivals is creating a high quality of service at a destination in a sustainable manner. The main purpose of this study is to analyze both what image the tourists have about Kuşadası as exemplified in the 15,047 reviews on TripAdvisor through content analysis, and what image the stakeholders have in their minds through interviews. The importance of this study is that it sheds light on the destination image that is stimulated through tourists' user-generated content based on the destination quality attributes.
\end{abstract}

Keywords: Destination image, destination quality, TripAdvisor

\section{Introduction}

The destination is referred to as the combination of a distinctive experience and commodity possibilities (Kuo, 2003). Heath and Wall (1991) note that the term 'tourism product' in a destination is an affair accomplished through various clusters of products and services. Thus, diverse divisions of the tourism enterprises are playing out their specific responsibilities in adding to the success of a destination (Ortigueira, Gómez-Selemeneva, 2011). In this sense, destinations all around the globe try to give tourists high quality of services with different components keeping in mind the end goal to fulfill their necessities (Hernandez-Mogollon et al., 2014). Kandampully et al. (2001) also state that the last evaluation of quality service of tourism does not depend entirely on the result of service, but likewise on the service procedure. Besides, to comprehend the multifaceted nature of services, there is a different approach that defines services as deeds, processes, and performances given or co-created by one element or individual (Van et al., 2009).

Today, tourism destinations that are an amalgam of tourism products are attempting to be more competitive (Zainuddin et al., 2016) and in recent years competitiveness has progressively been viewed as a basic instrument on the performance of tourism destinations (Meng,

\footnotetext{
Olympos Lodge, Cirali PK 38, Kemer/Antalya

Yasar University, Ağaçlı Yol Bornova, İzmir 35100, Corresponding author: gokce.ozdemir@yasar.edu.tr
} 
2006). Ritchie and Crouch (2003) posit that a tourism destination must grasp an incorporated approach towards the many elements of tourism products if to succeed. Service quality is perhaps the most imperative standard for competition in a tourism enterprise (Poon, 1993) and destination is conceivably a blend of every operation/business, commodities and eventually, local adventures supplied (Cooper et al., 1998). In this regard, destinations are striving hard to establish a superior service quality and to create a distinctive image. This research intends to identify the quality attributes of a destination for favorable image creation and sustainable tourism development focused on Kuşadası as a case study through two significant types of research that complement each other. In the next section, the literature review for destination quality and the image is given. This is followed by an account of the methodology used to conduct interviews and make the content analysis of TripAdvisor reviews posted by international tourists. Then the findings are presented, and the final discussion section gathers insights drawn from the various findings.

\section{Litrerature Review}

Success depends on the value of products and services that tourists have at a destination (Dwyer, Kim, 2003), and the challenge in managing a destination is the presence of many providers and service makers. In this vein, Wang (2011) notes that managing a destination can be characterized as a proactive, guest-focused way that coordinates the interests of tourists, service suppliers, and the community. The tourism value chain operations inside destinations perform visitors' experience at the destination where the quality of the product is very significant and closely connected to the destination's performance (Weiermair, Fuchs, 1999). Go and Govers (200o) also posits that destination quality merits a far-reaching approach and a complete reconciliation among its key stakeholders. According to Woods and Deegan (2003), the service quality shows the significance of reflecting the desires of buyers and offering a guarantee of service, making sure that the commodities produced, match that of the organizational standards. In other words, service quality is observed to be 'the result of an assessment procedure, where the buyer compares his desires and the services rendered to the consumer' (Tosun et al., 2015). In this sense, tourism administrators endeavor to enhance the quality and satisfaction of guests with the conviction that will make guests not to regret choosing a particular destination and will also enable them to return to the destination or even be willing to tell their acquaintances (Tian-Cole, Crompton, 2003).

Destination quality incorporates physical products and services also involving the natural and unadulterated magnificence of a destination (Tosun et al., 2015). A destination's universal quality framework involves pathway systems, air terminals, railway networks, transportation methods, telecom, garbage, distribution of water, social insurance offices, cleanliness, electricity, pecuniary administrations, and internet operations (Dwyer, Kim, 2003). Therefore destination quality is fundamentally assessed considering those, and also the cultural attributes of a tourism destination such as gastronomy, fine arts, music, folklore and dance (Murphy et al., 200o). The atmosphere, greenery, physical geography, landscape and many more valuable resources of a tourism destination (Dwyer, Kim, 2003) in addition to the superstructure of the tourism industry at the destination also reflects the quality attributes of a destination. Therefore, destination providers need to create images to achieve an increase in the number of tourists by continually maintaining and raising the quality of their places, and at last shape a positive image of their destination in general (Onder, Marchiori, 2016). 
New advancements and fast changes in the business conditions, tourism markets, and structures, and customer needs continuously challenge tourism destination managers in several ways (Gretzel et al., 200o). The most significant change originates from the advent of the internet which transformed the position of travel enterprises as information suppliers (Standing et al., 2014). Today, an ever-increasing number of travelers are using the website and on-line assets for their information requirements (Gursoy, McCleary, 2004). However, Govers et al. (2007) state that the internet can cause disarray and worry in purchasers, driving them to build up a more terrible image of the destination they are assessing. Thus, different online networking sites challenge the brand image depicted by the official destination websites (Kim, Fesenmaier, 2008). The brand image of a destination influences travelers' intended purpose of visiting a destination (Echtner, Ritchie, 1993). Therefore, the positive the image of a destination that a tourist has, the more noteworthy the probability that he or she would tell other potential tourists (Zhang et al., 2014). In this regard, social media networks allow tourists to do reviews, to assemble user-generated content, and transmit reviews to potential tourists (Taecharungroj, Mathayomchan, 2019).

For tourists, online reviews are not only a way of securing information but also the essence of making tourism decisions (Hou et al., 2019). Tourists or consumers often gather destination information before making a trip to a particular destination. The major source of information for tourists is the internet, which helps many tourists to look into a particular destination before embarking on a journey and to know the safety and dangers that lie ahead at the destination. Thereby, useful and credible information that is generated either by tourists or by marketers may play a crucial role in the tourist's decision-making process. Furthermore, with the expectation of getting a holistic destination experience, the tourists invest so much money and time (Vatter, 2014). In this sense, the destination image is perceived as a standout amongst the most critical factors in destination marketing (Kotler, Gartner, 2002). Since travelers are broadly pulled in to destinations by the mix of attractions, events, and experiences that they offer (Baloglu, McCleary, 1999), strategies are applied to convey a positive image in the minds of the tourists by focusing on the attributes that both distinguish and characterize the destination. Besides, understanding the image of a destination influencing potential tourists' motivation and attitude is consequently essential (Yuksel, Akgul, 2007).

\section{Methodology}

In recent decades, Turkey has encountered a noteworthy development in tourist numbers. Equivalent to the quick advancement of Turkish tourism, the city of Kuşadası has turned out to be one of the top destinations in Turkey (Yuksel, 2004). Kuşadası, situated on the Western Turkish drift, is one of Turkey's shoreline resort towns. It has especially various assets to pull in travelers, and the two main ones are its atmosphere and famously notable spots in its vicinity. The beginning of booming tourism in Kuşadası has started when a holiday camp was built in the town by a French company in 1967 , followed by cruise tours. Kuşadası is the most important cruise destination in Turkey with the port of Kuşadası with an annual capacity of 2,400 cruises. According to the official statistics of 2019 declared by the Ministry of Tourism and Culture, Kuşadası's accommodation capacity has reached over 367 lodging facilities with 16,876 rooms and 37,735 beds. 


\section{Sources of data}

In terms of qualitative methodology, primary data for this research was collected through the content analysis of Kuşadası reviews on TripAdvisor that is the commonly used social network site by tourists to gather accurate information. 463 million travelers use TripAdvisor each month, browsing more than 859 million reviews and opinions of 8.6 million accommodations, restaurants, experiences, airlines, and cruises. It is evident that TripAdvisor is the most popular and important website that connects intended tourists through online reviews on tourism matters. In the case of Kuşadası, tourists who left reviews with or without pictures taken by them after their visit to the destination was evaluated in terms of destination quality.

The subsequent qualitative methodology used in this particular study is semi-structured interviews that are conducted by the researchers with several tourism stakeholders of Kuşadasi. The reason to choose that method was to reach and collect detailed opinions of selected participants and understand the concept of destination image of Kuşadası more deeply. The interview form that is prepared by the researchers was based on the literature review (Baloglu, McCleary, 1999; Echtner, Ritchie, 1993; Zhang et al., 2014), and contained 10 open-ended questions about destination quality and destination image of Kuşadası in particular. Face-toface individual interviews were conducted among twenty stakeholders in Kuşadası destination which includes travel agencies (3), restaurants (3), beach clubs (2), residents (3), and both domestic and international tourists (9).

\section{Data Collection and analysis}

In the primary research, reviews about Kuşadası are contents analyzed to reach a quality ranking of the destination which facilitates the creation of destination image. According to Kippendorff (2004), content analysis in qualitative research includes close perusing of moderately little measures of information; communication data, interpretation of verbal, symbolic and pictorial; and the inclusion of the researcher with the study of information translation. Therefore, content analysis of TripAdvisor, a social networking site that allows users to generate content, was performed after a search through Trip Advisor about Kuşadası and then Google translation was used to reach broader reviews in different languages. The analysis through user-generated content that reflects the destination image is conducted between the 6/10/2017 to $24 / 10 / 2017$ and reviews on the section "Things to do in Kuşadası" were analyzed. There were 15,047 reviews (including all the languages) in the respective category of TripAdvisor. The findings reveal the assessment of reviews of each attraction as positive $(\mathrm{P})$, average $(\mathrm{A})$ and negative $(\mathrm{N})$ with the statements that are most frequently emphasized.

To overcome the one-sided approach, additional interviews were conducted about Kuşadasi to produce an elaborate insight as the information on TripAdvisor reflects only the tourist's point of view. An open-ended question form with ten questions was used during the semi-structured interview conducted in Kuşadası, and detailed analysis was derived from the answers of the participants. Both the snowball sampling and convenience sampling methods were used to identify the potential participants for the interviews, with twenty participants agreeing to participate in the study whereas others had refused or were unavailable. The interviews were conducted with the tourism stakeholders of the destination Kuşadası, such as domestic and international tourists, residents, travel agents, restaurant owners, and beach club managers. The purpose of the study was to find out about the destination image of Kuşadası. 
Therefore, it aimed to measure the perceptions stakeholders are holding about Kuşadası and covered relevant interview questions primarily based on destination image and quality attributes such as infrastructure, facilities, and attractions. Through the interviews undertaken by the researchers, ways to improve services delivered and to enhance the satisfaction of tourists are identified. Only important responses were picked and featured in the research findings since almost similar responses were gathered from the whole group of participants.

\section{Research Findings}

\section{Research 1: Content analysis of tourist reviews on TripAdvisor}

The findings involve the comments and opinions of tourists (both international and national) that have visited Kuşadası. Table 1 below reveals the frequency of positive, negative and average reviews for attractions in Kuşadası.

Table 1. Frequency of attractions in Kuşadası

\begin{tabular}{|c|c|c|c|}
\hline Attractions of Kuşadası & \multicolumn{3}{|c|}{ Frequency } \\
\hline Dilek National Park (Güzelçamlı) & $\mathrm{P}$ & A & $\mathrm{N}$ \\
\hline Amazing park/clean water with lots of events to explore & 461 & & \\
\hline Lovely natural park/beautiful beach/nice boat cruise & 169 & & \\
\hline An average tourism destination & & 36 & \\
\hline Bad and disappointed & & & 20 \\
\hline Adaland Aquapark & $P$ & A & $\mathrm{N}$ \\
\hline Excellent and amazing waterpark and water slides & 623 & & \\
\hline Very nice and clean aquapark & 353 & & \\
\hline Average and normal park & & 124 & \\
\hline Bad and disappointed & & & 69 \\
\hline Kuşadası Castle & $P$ & A & $\mathrm{N}$ \\
\hline Wonderful and beautiful scenery & 166 & & \\
\hline Very good piece of architecture & 154 & & \\
\hline Normal castle (not so special) & & 101 & \\
\hline Disappointed & & & 36 \\
\hline Ladies Beach & $\mathrm{P}$ & A & $\mathrm{N}$ \\
\hline Great and beautiful beach/friendly staff & 563 & & \\
\hline Lovely restaurants and food & 493 & & \\
\hline Average beach and overpriced & & 326 & \\
\hline Overrated, disappointed \& very dirty and polluted water & & & 226 \\
\hline Uzun Beach & P & A & $\mathrm{N}$ \\
\hline Excellent, quiet and calm beach/ Richness of beach amenities & 221 & & \\
\hline Clean \& clear water/best home cooked meal & 139 & & \\
\hline Average and overrated beach & & 73 & \\
\hline Dirty and filthy beach & & & 34 \\
\hline
\end{tabular}




\begin{tabular}{|c|c|c|c|}
\hline Attractions of Kuşadası & & equen & \\
\hline Tortuga Waterpark & P & A & $\mathrm{N}$ \\
\hline Nice and clean park/Friendly staff/Fantastic and amazing place to be & 39 & & \\
\hline Lovely place for all ages & 15 & & \\
\hline Average waterpark & & 2 & \\
\hline Kuşadası Market & P & A & $\mathrm{N}$ \\
\hline Best bazaar/Quality market products & 222 & & \\
\hline Lovely brand counterfeit & 221 & & \\
\hline Only enjoyable for sightseeing and not to purchase & & 171 & \\
\hline Dubious market sellers, overpriced for international tourists, overcrowded and too much hassle & & & 146 \\
\hline Silver Sand Beach & $P$ & A & N \\
\hline Best Kuşadası beach/Clean waters & 45 & & \\
\hline Availability of beach amenities/Good and cheap food & 14 & & \\
\hline Average beach & & 7 & \\
\hline Poor beach, services and rude staff & & & 4 \\
\hline Kuşadası Shopping Center & $P$ & A & $\mathrm{N}$ \\
\hline Nice and quiet mall & 22 & & \\
\hline Quality products/ Pricy but nice bargain & 15 & & \\
\hline Average & & 6 & \\
\hline Awful and unfriendly storekeepers, bad shopping place & & & 3 \\
\hline Downtown Beach & $P$ & A & N \\
\hline Best and lovelybeach/nice cruise ship & 9 & & \\
\hline Very good and clean beach & 11 & & \\
\hline Average beach & & 9 & \\
\hline Disappointed & & & 4 \\
\hline Gazi Begendi Park & $P$ & A & N \\
\hline Amazing view & 14 & & \\
\hline Best restaurant/good food & 12 & & \\
\hline Average/just ok restaurant & & 2 & \\
\hline Disappointed & & & 6 \\
\hline Sevgi Beach (Davutlar) & $P$ & A & $\mathrm{N}$ \\
\hline Amazing and exciting & 11 & & \\
\hline Very good beach with beach amenities & 11 & & \\
\hline Average beach & & 9 & \\
\hline Dirty beach/ disappointed & & & 8 \\
\hline Kadıkalesi Anaia Excavations & $P$ & A & N \\
\hline Wonderful historical site & 4 & & \\
\hline Very good castle & 2 & & \\
\hline Average site & & 2 & \\
\hline Poor historical site & & & 1 \\
\hline Panionion (Güzelçamlı) & $P$ & A & $\mathrm{N}$ \\
\hline Fantastic historical place & 2 & & \\
\hline Very lovely history & 1 & & \\
\hline
\end{tabular}




\begin{tabular}{|c|c|c|c|}
\hline Attractions of Kuşadası & \multicolumn{3}{|c|}{ Frequency } \\
\hline Just an average historical space & & 5 & \\
\hline Disappointed & & & 1 \\
\hline Kaleiçi Mosque & $P$ & A & $\mathrm{N}$ \\
\hline Very good and beautiful mosque & 5 & & \\
\hline Average mosque & & 1 & \\
\hline Old Town Tanneries & $P$ & A & $\mathrm{N}$ \\
\hline Amazing scenery & 1 & & \\
\hline Kafkas Spice Bazaar and Home Wine Spice Market & $P$ & $A$ & $\mathrm{~N}$ \\
\hline Best ice cream in town & 1 & & \\
\hline Aqua Atlantis & $P$ & A & $\mathrm{N}$ \\
\hline Best and excellent waterpark & 1 & & \\
\hline An average waterpark & & 3 & \\
\hline Bad and terrible place to be & & & 13 \\
\hline
\end{tabular}

The results of this research reveal the assessments of different reviews and opinions of tourists through the comments that were left on TripAdvisor. According to Dilek National Park (Güzelçamlı) reviews, the result shows that 461 tourists think that the attraction is of great quality which is commonly referred to as an "Amazing park" with clean water and lots of events to explore for both adults and children. On the other hand, 20 reviews involved tourists' disappointment due to water pollution and bad experience with the staff and so on. It is observed from the reviews that Gazi Beğendi Park, a mini-park situated on the hill alongside a restaurant, although not as popular as Dilek National Park, the comments are mostly positive. Another attraction, Tortuga Water Park is a unique park that has only positive reviews. 39 tourists find the attraction amazingly beautiful, nice and clean, with friendly staff and a fantastic place to be. Adaland seems to be an exciting aquapark for tourists, as 623 tourists declare through positive reviews and 69 negative reviews are mostly about the provision of services by the staff and bad environment as a whole. Another tourism attraction Aqua Atlantis has an excellent and amazing waterpark and slides with 353 tourists considering it to be a very nice and clean aquapark whereas 13 tourists regard it as a bad and terrible place to be.

Ladies Beach, one of the most popular tourist attractions in Kuşadası, is a great and beautiful beach with much friendly staff according to the comments of 569 tourists. 493 tourists think that the beach is very lovely and it is surrounded by good restaurants that make good food, while 326 tourists think that, the Ladies beach is an average quality of attraction with overpriced products. Additionally, 226 tourists seem to be disappointed and think that the beach is overrated, very dirty and has polluted water. Also, 221 consumers review Uzun Beach, known to be bigger and better than Ladies beach, as an excellent, quiet and calm beach, with the availability of various beach amenities. 139 tourists rate the beach as very good, having clean \& clear water with restaurants by the side that provide the best meal. Although Silver Sand Beach and Downtown Beach are among the least reviewed beaches on TripAdvisor, 45 reviews reveal that Silver Sand Beach is the best beach in Kuşadası with clean water, and Downtown Beach is a lovely beach according to the positive reviews of 20 tourists.

Kuşadası Market is a must-visit for everyone touring Kuşadası as the visitors have declared. 222 tourist reviews emphasize that it is the best bazaar with high-quality products and 221 tourists state that, it has the best counterfeited branded products that look like the original ones. 171 reviews show that Kuşadası Market is only good for sightseeing and not to purchase 
goods and products. Lastly, 146 tourists happened to be very disappointed with the dubious act that is common among the sellers, doubling the price of products for the international tourists, and it is also an overcrowded place with too much hassle which is not kids friendly. Kuşadası Shopping Center is another shopping attraction for tourists as 22 tourists state that it is a nice and quiet mall, while, 3 reviews show that the shopping center offers a bad shopping experience.

Kuşadası Castle is a wonderful place to be with beautiful scenery based on the 166 tourists that visited the relevant attraction. 154 reviews show that Kuşadası Castle is a very good piece of architecture and 101 tourists think that, it is an average or normal attraction with no important image to hold on to. Additionally, 36 tourists are disappointed and think visiting the attraction is a total waste of time and money. On the other hand, only 9 tourists reviewed Kadıkalesi Anaia Excavations and 6 tourists consider it is as an important historical site. Meanwhile, 2 tourists think that it is an average site with no important history and 1 claims that it is a poor historical site. Panionion (Güzelçamlı) was one of the least reviewed attractions on TripAdvisor, with only 9 reviews, of which 8 of them were positive stating that, the attraction is of high and moderate quality. Another least reviewed attraction on TripAdvisor is Kaleici Mosque with 6 reviews and having no negative comment. In Old Town Tanneries, there is only 1 review by a tourist and the tourist feels it has amazing scenery. One of the tourist attractions of Kuşadası specified in TripAdvisor is Kafkas Spice Bazaar and Home Wine Spice Market and it has only 1 review.

\section{Research 2: Interviews with stakeholders}

The first research involved the assessments of semi-structured interviews with some stakeholders that contribute to the quality of tourism experience in Kuşadasi. The research findings and the results were interpreted and the most valuable answers were picked accordingly. The stakeholders of Kuşadası have given various answers to the questions about the quality of the destination. Some participants had emphasized that Kuşadası is rich in terms of infrastructure, history, and entertainment but others declared that recent tourism in Kuşadası has been drastically declining due to water pollution, over-construction and unsophisticated sewage system. It has been observed that some participants highlighted the destination as of good quality, while others mostly underlined a negative point of view. In addition, both international and domestic tourists think that there is a unique predicament befalling the tourism destination concerning the issue of the destruction of some natural beauty which is supposed to serve as tourist attractions. The participants of the interview also stated that some major places in the destination need a lot of renovation. The participants set a high value in reading about the history of the region and experiencing it with guided tours in ancient cities that leave a lasting memory in the hearts of the guests.

"Kuşadast is of high quality as a whole, there is nothing like sea pollution, the roads, landscape and all are well managed and organized, everything here is neat and properly shaped."

International Tourist from Ireland.

On the other hand, research findings reveal that accommodation in Kuşadası is of great quality in terms of neatness in the surroundings and facilities. It was gathered that hotels in Turkey as a whole take hospitality seriously as to make the guests more comfortable and 
to also create positive word-of-mouth. As the findings indicate, the tourism environment, in general, is mainly well managed and of high quality being aware that there are some exceptional places in Kuşadası which are not neat and well taken care of. The quality of a destination also depends on the residents' attitudes towards tourists. The findings reveal that the residents are quite friendly and willing to help others. The results show that the residents make it their duty to look after the guests which make the city a pleasant place for tourists to visit. The locals, being a major factor of tourism represents a meaningful subject in destination development and Kuşadası, as a tourism destination has greatly been formed and affected by this factor positively.

"Locals are good for tourists because we need them to sell our products and services, so, we need to try our best to make them feel comfortable.."

Resident 2

One of the questions in the interview involved if the quality was well-reflected to the tourists through communication channels. Promotion of a destination is a major way of creating awareness about a tourism destination to get people to visit and by visiting a destination, tourists directly or indirectly contribute to the growth of the destination. The interviews with the stakeholders were mainly focused on the lack of effective promotion on an international basis. As the participants implied, word of mouth and also promotions of tour operators or travel agencies were playing a significant role in the tourists' decision-making process.

"I would recommend that they promote and advertise Kuşadası more because people are now scared to come for tourism this year and seriously, no terrorism whatsoever in this city, it is all fun, history, and enjoyment here"

Restaurant Manager 2

\section{Discussion and Conclusion}

According to the two types of research carried out, it was gathered that many tourists, especially the international tourists visit Kuşadası mainly because of its richness in history and the amenities provided for sea, sun and sand tourism. Based on the findings, it is clear that the destination quality of Kuşadası leaves many tourists impressed with the tourism services rendered at the destination. The findings of the study reveal that tourists in Kuşadası favor the authenticity of historical places, natural attractions, tourism services and unending care of the local community. The historical attractions that surround the destination make the city valuable for tourists to visit, and interaction with locals enables the exchange of culture that exposes tourists to Turkish socio-economic background, religion, traditions, cuisine and so forth. The study also shows that the tourism superstructure of Kuşadası is of high quality with its holiday resort hotels. On the other hand, common unfavorable issues that are identified in both research 1 and 2 are mainly about infrastructural problems of the destination which leads to environmental pollution. Those problems holding a potential threat for the future of the tourism industry are not only recognized by the tourists but also the stakeholders of the destination which requires taking a considerable amount of effective measures, to prevent the degradation of the environment. To sum up, the results of the researches indicate that Kuşadası achieved an overall positive destination image in the minds of the tourists, but it's not with- 
out its problems. Therefore, the findings point out that despite the strengths of the destination Kuşadası, many weaknesses have to be dealt with to create sustainable tourism at the destination. The findings of this study are in parallel with Lee \& Xue (2020)'s research, which analyzes attributes of a destination, such as tourist attractions, environmental conditions, and infrastructures in terms of sustainability.

From a scholarly point of view, this study investigates how the quality of the destination affects destination image through user-generated content on social media sites. Social media networks like TripAdvisor allows the widespread distribution of tourism experiences and creates a word-of-mouth effect. Consistent with Qi \& Chen (2019), the study highlights that user-generated content on TripAdvisor stimulates other tourists as an information source and has a major role in the image formation of destinations. From a managerial point of view, the findings are useful for the destination marketers as Kuşadası's image has a strong association with sea, sun, and sand tourism supported by cultural attributes. Dependence of Kuşadası on ${ }_{3} \mathrm{~S}$ tourism makes environmental issues of top priority, thus destination managers have to take necessary actions to prevent the pollution which may lead to the loss of Kuşadası's attractiveness in the future. To ensure sustainable tourism in the resort town, those reviews can be used in favor of tourism development by the public and private tourism authorities. To enhance the tourist experience, destination management organizations should thoroughly understand the challenges and threats the destinations are facing. In light of the findings, if destination quality is properly managed and improved, it may lead to favorable user-generated content reflecting a positive destination image. Although the reviews on TripAdvisor are uncontrollable, social media sites should be closely tracked and responded to instantly to minimize the negative impacts of bad reviews on prospective tourists. The study has many limitations; one limitation of the research is that, the star ratings of Kuşadası attractions on TripAdvisor were not covered as it was not clear on the website how the reviews of the attractions were calculated and concluded at the star ratings. Another limitation was the dependence of the research on only one social media network, and excluding the others.

\section{References}

Baloglu, S., McCleary, K. W. 1999. A model of destination image formation. Annals of Tourism Research 26 (4), 868-897.

Qi, S., Chen, N. 2019. Understanding Macao's destination image through user-generated content. Journal of China Tourism Research 15(4), 503-519.

Cooper, C., Fletcher, J., Gilbert, D., Shepherd, R., Wanhill, S. (eds). 1998. Tourism, Principles and Practices. 2nd ed, Addison Wesley Longman, England.

Dwyer, L., Kim, C. 2003. Destination competitiveness: Determinants and indicators. Current Issues in Tourism 6 (5), 369-414.

Echtner, C.M., Ritchie, J. R. B. 1993. The measurement of destination image: An empirical assessment. Journal of Travel Research 31 (4), 3-13.

Go Frank M., Govers, R. 20oo. Integrated quality management for tourist destinations: A European perspective on achieving competitiveness. Tourism Management 21, 79-88.

Govers, R., Go Frank, M., Kumar, K. 2007b. Promoting Tourism Destination image. Journal of Travel Research 46, 15-23. 
Gretzel, U., Yuan, Y., Fesenmaier, D. R. 20oo. Preparing for the new economy: "Advertising strategies and change in destination marketing organization". Journal of Travel Research 39 (2), 146-56.

Grönroos, C. 2007. Service management and marketing: customer management in service competition. John Wiley \& Sons.

Gursoy, D., McCleary, K. W. 2004. An integrative model of tourist's information search behavior. Annals of Tourism Research 31, 353-373.

Harris, R., Howard, J. 1996. Dictionary of Travel E Tourism Hospitality Terms. Melbourne, Hospitality Press.

Heath, E., Wall, G. 1991. Marketing tourism destinations: a strategic planning approach. John Wiley \& Sons, Inc.

Hernandez-Mogollon, J. M., Folgado-Fernandez J. A., Duarte P. A. O. 2014. Event tourism analysis and state of the art. European Journal of Tourism, Hospitality and Recreation 5 (2), 83102.

Hou, Z., Cui, F., Meng, Y., Lian, T., Yu, C. 2019. Opinion mining from online travel reviews: A comparative analysis of Chinese major OTAs using semantic association analysis. Tourism Management 74, 276-289.

Kandampully, J., Mok, C., Sparks B. (Eds.) 2001. Service quality management in hospitality tourism and leisure, New York: Haworth Hospitality Press, 26.

Kim, H., Fesenmaier, D. R. 2008. Persuasive design of destination websites: An analysis of first impression. Journal of Travel Research 47 (3), 3-13.

Kotler, P., Gertner, D. 2002. Country as brand, product and beyond. A place of marketing and brand perspective. Journal of Brand Management 9(4-5), 249-261.

Kuo, Y. F. 2003. A study on service quality of virtual community websites. Total Quality Management \& Business Excellence 13 (4), 461-473.

Lee, S.W., Xue, K. 2020. A model of destination loyalty: Integrating destination image and sustainable tourism. Asia Pacific Journal of Tourism Research 25(4), 393-408.

Meng, F. 2006. An examination of destination competitiveness from the tourists' perspective: The relationship between quality of tourism experience and perceived destination competitiveness (Ph.D. dissertation). Virginia Polytechnic Institute and State University.

Murphy, P., Pritchard, M., Smith, B. 20oo. The destination Product and its impacts on travelers' perceptions. Tourism Management 21 (1), 43-52.

Onder, I., Marchiori, E. 2016. A comparison of pre-visit beliefs and projected visual images of destinations. Tourism Management Perspectives 21, 42-53.

Ortigueira, L. C., Gómez-Selemeneva, D. 2011. Critical success factors of a tourist destination in the Caribbean. Book of proceedings Vol. 1 - International Conference on Tourism \& Management Studies - Algarve 2011.

Ritchie, J. R. B., Crouch, G. I. 2003. The competitive destination, a sustainable tourism perspective. Cambridge: Cabi Publishing.

Standing, C., Tang-Taye, J-P., Boyer, M. 2014. The Impact of the Internet in Travel \& Tourism: A research review 2001-2010. Journal of Travel \& Tourism Marketing 31 (1), 82-113.

Taecharungroj, V., Mathayomchan, B. 2019. Analysing TripAdvisor reviews of tourist attractions in Phuket, Thailand. Tourism Management 75, 550-568.

Tian-Cole, S., Crompton, J. L. 2003. A conceptual of the relationship between service quality and visitor satisfaction and their links to destination selection. Leisure Studies 22, 65-80. 
Tosun, C., Bekir, B. D., Fyall, A. 2015. Destination service quality, affective image and revisit intention: The moderating role of past experience. Journal of Destination Marketing $\mathcal{E}$ Management 4, 222-234.

Vatter, O. 2014. Communication in destination marketing case study: Tallinn European Capital of Culture 2011. Procedia-Social and Behavioral Sciences 148, 170-176.

Wang, Y. 2011. Destination marketing and management: Scope, definition and structures. In Y. Y. Wang, \& A. Pizam (Eds.), Destination marketing and management: Theories and applications (pp. 1-20). Wallingford, UK: CAB International.

Weiermair, K., Fuchs, M. 1999. Tourist and retailers perceptions of services. Annals of Tourism Research 26, 1004-1021.

Woods, M., Deegan, J. 2003. A warm welcome for Destination quality brands: The examples of the pays Cathere region. International Journal of Tourism Research 5, 269-282.

World Tourism Organization. 2007. A practical guide to tourism destination management.

Yuksel, A. 2004. Shopping experience evaluation: A case of domestic and International visitors. Tourism Management 25, 751-759.

Yuksel, A., Akgul O. 2007. Postcards as affective image makers: An idle agent in destination marketing. Tourism Management 28, 714-725.

Zainuddin, Z., Radzi, S. M., Zahari, M. S. M. 2016. Perceived destination competitiveness of Langkawi Island, Malaysia. Procedia-Social and Behavioral Sciences 222, 390-397.

Zhang, H., Fu, X., Cai, L.A., Lu, L. 2014. Destination Image and Tourist Loyalty: A Meta-Analysis. Tourism Management 40, 213-223. 